\title{
Association of Cross Linked C-Telopeptide II Collagen and Hyaluronic Acid with Knee Osteoarthritis Severity
}

\author{
John Butar Butar ${ }^{1, *}$, Zola Wijayanti ${ }^{1}$, Beatrix Tjahyana ${ }^{1}$, Veli Sunggono ${ }^{2}$, Hori Harianto ${ }^{3}$ \\ ${ }^{1}$ Orthopedic Department, Siloam Hospital Lippo Village, Jl. Siloam No.6 Lippo Karawaci 15811, Tangerang, Indonesia \\ ${ }^{2}$ Department of Public Health, Faculty of Medicine Universitas Pelita Harapan, Jl. Boulevard Jend. Sudirman Lippo Karawaci, Tangerang, Indonesia \\ ${ }^{3}$ Anesthetic and Intensive Care Department, Siloam Hospital Lippo Village, Jl. Siloam No. 6 Lippo Karawaci 15811, Tangerang, Indonesia \\ *Corresponding author. E-mail: johnbutar2@gmail.com
}

\section{Abstract}

B ACKGROUND: This study was carried out to investigate the association of Cross Linked C-Telopeptide Type I \& II Collagen (CTX-I and II) and hyaluronic acid (HA) with knee osteoarthritis (OA) severity.

METHODS: Sixty menopause women with primary knee OA were enrolled in this study during their visits to the Outpatient Department. Patients with knee pain during weight bearing, active or passive range of motion, or tenderness with Kellgren-Lawrence (KL) grade of more than I were included. Patients with injury, inflammatory and metabolic diseases were excluded. Patients were put in a 10hour fasting prior to withdrawal of morning blood samples for examinations of HA, CTX-I, interleukin 1 beta (IL$1 \beta$ ), and high sensitivity $\mathrm{C}$ reactive protein (hs-CRP) level. Second void morning urine specimens were taken for CTXII assessment. HA, CTX-I and II levels were measured by enzyme-linked immunosorbent assay.

RESULTS: Sixty menopausal female patients were included in this study, 35 with KL grade II, 17 grade III, and 8 grade IV. Means of CTX-II were significantly different between subjects KL grade IV and III $(p=0.021)$. Correlation of KL grade was significant with CTX-II $(p=0.001, \mathrm{r}=0.412)$ and HA ( $p=0.0411, \mathrm{r}=0.269)$. KL grades were not significantly associated with CTX-I $(p=0.8364, \mathrm{r}=-0.0272) ; \quad \mathrm{IL}-1 \beta$ $(p=0.5773, \mathrm{r}=0.0853)$ and hs-CRP $(p=0.2625, \mathrm{r}=0.1470)$.

CONCLUSION: CTX-II and HA were associated with severity of knee OA, suggesting that CTX-II and HA can be used as marker for knee OA severity.

\section{Abstrak}

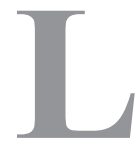

ATAR BELAKANG: Untuk mengetahui hubungan antara Cross Linked C-Telopeptide Type I \& II Collagen (CTX-I dan II), dan hyaluronic acid (HA) dengan keparahan osteoarthritis (OA) pada lutut.

METODE: Penelitian ini melibatkan 60 wanita menopause dengan OA lutut pada bagian rawat jalan, dengan keluhan nyeri lutut saat mengangkat beban, melakukan gerakan aktif dan pasif, atau tingkat kelembutan yang masuk dalam Kellgren-Lawrence (KL) grade lebih dari I. Pasien dengan luka, inflamasi dan penyakit metabolik dieksklusi. Pasien diminta untuk puasa selama 10 jam sebelum pengambilan darah di pagi hari untuk pemeriksaan kadar HA, CTX-I, interleukin 1 beta (IL-1 $\beta$ ) dan high sensitivity $C$ reactive protein (hs-CRP). Sampel urin kedua di pagi hari diambil untuk pemeriksaan CTX-II. HA, CTX-I dan II diperiksa dengan enzyme-linked immunosorbent assay.

HASIL: Enampuluh wanita menopause mengikuti penelitian ini, 35 dalam kelompok KL tingkat II, 17 tingkat III, dan 8 tingkat IV. Rerata CTX-II berbeda bermakna antara subyek KL tingkat III dan IV $(p=0,021)$. Ditemukan korelasi yang bermakna antara tingkatan KL dengan CTX-II $(p=0,001, \mathrm{r}=0,412)$, dan HA $(p=0,0411, \mathrm{r}=0,269)$. Tingkat KL tidak berkorelasi bermakna dengan CTX-I ( $p=0,8364$, $\mathrm{r}=-0,0272), \quad \mathrm{IL}-1 \beta \quad(p=0,5773, \quad \mathrm{r}=0,0853) \quad$ dan $\mathrm{hs}-\mathrm{CRP}$ $(p=0.2625, \mathrm{r}=0.1470)$.

KESIMPULAN: CTX-II dan HA berhubungan dengan tingkat keparahan OA lutut, sehingga CTX-II dan HA dapat digunakan sebagai penanda untuk keparahan OA. 
KEYWORDS: CTX-II, hyaluronic acid, otestoarthritis, knee

Indones Biomed J. 2013; 5(3): 179-84
KATA KUNCI: CTX - II, asam hyaluronat, osteoartritis, lutut

\section{Introduction}

As a chronic progressive disorder, knee osteoarthritis (OA) is marked by damage on cartilage and subchondral bone, and synovial thickening. The damage is a manifestation of imbalance between degradation and repair processes.(1) The extent of OA assessed by radiographic characteristics cannot be used in early diagnosis and prediction of progression due to low sensitivity. Therefore, developing a more sensitive indicator that can be used alongside with radiographic technique is important.(2)

Many efforts have been done to identify specific indicators using imaging and biomarker parameters.(3) Type I collagen, composed of nearly $90 \%$ organic matrix of bone, consists of triple helix of the two chains, alpha 1 and alpha 2. Level of urinary cross linked C-telopeptide type I collagen (CTX-I) was found higher in patients with progressive OA compared to non-progressive one and control.(4) C-telopeptide type II collagen (CTX-II) is a constituent of the articular cartilage and hyaline cartilage. Urinary CTXII correlated with pain, malfunction, joint gap narrowing and subchondral sclerosis.(5) Hyaluronic acid (HA) is a precursor of synovium and cartilage. Increased levels of HA in the blood occurs in osteoarthritis.(6) Several studies have shown that HA and CTX-II related to the severity of OA(715), but one study reported no correlation was found(16). Most studies were done on Caucasian subjects.

\section{Methods}

\section{Subjects}

Sixty menopause women with primary knee OA were enrolled to this study. Patients with knee pain during weight bearing, active or passive range of motion, or tenderness with Kellgren-Lawrence (KL) grade of more than grade I were included. Subjects underwent weight-bearing posteroanterior (PA) radiography and weight-bearing lateral radiography. Patients with inflammatory joint disease such as rheumatoid arthritis were excluded.

\section{Blood Samples Collection and Assessment}

Fasting morning blood samples were collected for HA, CTX-I and high sensitivity C-reactive protein (hs-CRP) assessment. Serum HA was measured with enzymelinked immunosorbent assay (ELISA) (Cat. No.: 029001, Corgenix, Broomfield, CO). CTX-I was measured by $\beta$-Crosslaps ELISA with sensitivity of $10 \mathrm{pg} / \mathrm{ml}$ (Cat. No.: 11972308, Roche, Indianapolis, IN). Meanwhile high sensitivity $\mathrm{C}$ reactive protein (hs-CRP) was measured using Cobas Integra, with standard range $\leq 10 \mathrm{mg} / \mathrm{L}$.

\section{Urine Samples Collection and Assessment}

Morning second void urine specimens were taken for CTXII assessment as recommended in a previous study based on diurnal and activity related variation $(17,18)$. Samples were measured using Urine CartiLaps EIA with sensitivity 0.20 $\mathrm{mg} / \mathrm{ml}$ (Immunodiagnostic Systems Ltd., Boldon, UK).

\section{Articular fluid}

Articular fluid of minimum $1 \mathrm{~mL}$ was taken for Interleukin 1 beta (IL-1 $\beta$ ) analysis. Samples were measured using ELISA with sensitivity $1 \mathrm{pg} / \mathrm{ml}$ (R\&D System, Minneapolis, MN).

\section{Radiographs}

Subjects underwent weight-bearing PA knee radiography in mild flexion.(19) KL grading system was used to assess severity of $\mathrm{OA}$, which included the formation of osteophytes, joint space narrowing, subchondral sclerosis and joint deformity. OA was classified based on KL grading into 5 grades: grade 0 (normal), grade 1 (doubtful OA), grade 2 (minimal OA), grade 3 (moderate OA), and grade 4 (severe OA). X-Ray was read by an orthopedic surgeon and a trained radiologist with inter-rater reliability kappa test 0.797 .

\section{Data Analysis}

Data analysis was done by SPSS version 20.0 (IBM Corp., Armonk, NY). Analysis of mean differences of biomarkers among the KL groups was done using Mann-Whitney U Test, and $p<0.05$ was defined as significant. The association between biomarkers and KL grades was analyzed using spearman correlation test.

\section{Results}

Sixty menopausal female patients were included in this study. Thirty five subjects (58\%) having KL grade II, 
Table 1. Distribution of Demographic, Radiographic and Laboratory Results.

\begin{tabular}{lccc}
\hline \multicolumn{1}{c}{ Variable } & Mean \pm SD & Minimum & Maximum \\
\hline Age (year) & $58.420 \pm 9.803$ & 42 & 83 \\
BMI $(\mathrm{kg} / \mathrm{m} 2)$ & $27.000 \pm 4.480$ & 20 & 39.26 \\
Affected Knee & & & \\
Left (\%) & $32.5 \%$ & $67.5 \%$ & \\
Right (\%) & & & \\
KL Grade & & $35 / 58.3 \%$ & \\
Grade II (n/\%) & $17 / 28.3 \%$ & & 1.18 \\
Grade III (n/\%) & & $8 / 13.3 \%$ & 2213 \\
Grade IV (n/\%) & $0.480 \pm 0.230$ & 0.12 & 1489 \\
CTX -I (ng/mL) & $719.630 \pm 438.560$ & 107 & 11.81 \\
CTX-II (ng/mmol) & $213.580 \pm 227.940$ & 57 & 26.20 \\
HA (ng/mL) & $2.110 \pm 2.230$ & 0 & \\
IL-1 $\beta$ (pg/mL) & $4.190 \pm 4.730$ & 0.20 & \\
hs-CRP (mg/L) & & & \\
\hline
\end{tabular}

Table 2. Mean Difference Test for Biomarkers in KL Group.

\begin{tabular}{|c|c|c|c|}
\hline Variable & $\mathbf{N}$ & Mean \pm SD & $p$ \\
\hline \multicolumn{4}{|l|}{ CTX-I } \\
\hline $\mathrm{KL} 2 * * *$ & 35 & $0.490 \pm 0.250$ & \\
\hline KL 3 & 17 & $0.438 \pm 0.210$ & $0.5070 *$ \\
\hline KL 4 & 8 & $0.470 \pm 0.180$ & $0.4660^{* *}$ \\
\hline \multicolumn{4}{|l|}{ CTX-II } \\
\hline KL 2 & 34 & $506.940 \pm 291.910$ & \\
\hline KL 3 & 16 & $731.140 \pm 428.460$ & $0.0650^{*}$ \\
\hline KL 4 & 8 & $1004.900 \pm 265.060$ & $0.0210 * *$ \\
\hline \multicolumn{4}{|l|}{ HA } \\
\hline KL 2 & 34 & $158.800 \pm 71.100$ & \\
\hline KL 3 & 16 & $198.550 \pm 103.590$ & $0.2277^{*}$ \\
\hline KL 4 & 8 & $209.850 \pm 93.420$ & $0.1510 * *$ \\
\hline \multicolumn{4}{|l|}{ IL- $1 \beta$} \\
\hline KL 2 & 23 & $2.120 \pm 2.170$ & \\
\hline KL 3 & 14 & $1.350 \pm 0.430$ & $0.4701 *$ \\
\hline KL 4 & 8 & $2.180 \pm 1.500$ & $0.0983 * *$ \\
\hline \multicolumn{4}{|l|}{ hs-CRP } \\
\hline KL 2 & 35 & $1.900 \pm 2.520$ & \\
\hline KL 3 & 17 & $5.420 \pm 5.440$ & $0.4293 *$ \\
\hline KL 4 & 8 & $4.270 \pm 3.130$ & $0.8714 * *$ \\
\hline
\end{tabular}

*: Mann-Whitney U Test KL 3 vs. KL 2; **: Mann-Whitney U Test KL 4 vs KL 3 
Tabel 3. Correlation of Biomarker with Kellgreen.

\begin{tabular}{lcc}
\hline \multirow{2}{*}{ Variable } & \multicolumn{2}{c}{ KL } \\
\cline { 2 - 3 } & $\mathbf{R}$ & $\boldsymbol{p}$ value \\
\hline CTX-I & -0.0272 & 0.8364 \\
CTX-II & 0.4120 & $\mathbf{0 . 0 0 1 0}$ \\
HA & 0.2690 & $\mathbf{0 . 0 4 1 1}$ \\
IL-1 $\beta$ & 0.0853 & 0.5773 \\
hs-CRP & 0.1470 & 0.2625 \\
\hline
\end{tabular}

17 subjects (28\%) having KL grade III, and 8 subjects (13\%) having KL grade IV. Two urine samples for CTXII examination and two blood samples for HA examination were spoiled hence not eligible for analysis. Fifteen samples of articular fluid for IL-1 $\beta$ examination were not adequately taken, thus not eligible for analysis. The average age of the participants was 58.42 years ( $42-83$ years old) and the average body mass index was $27 \pm 4.48$.

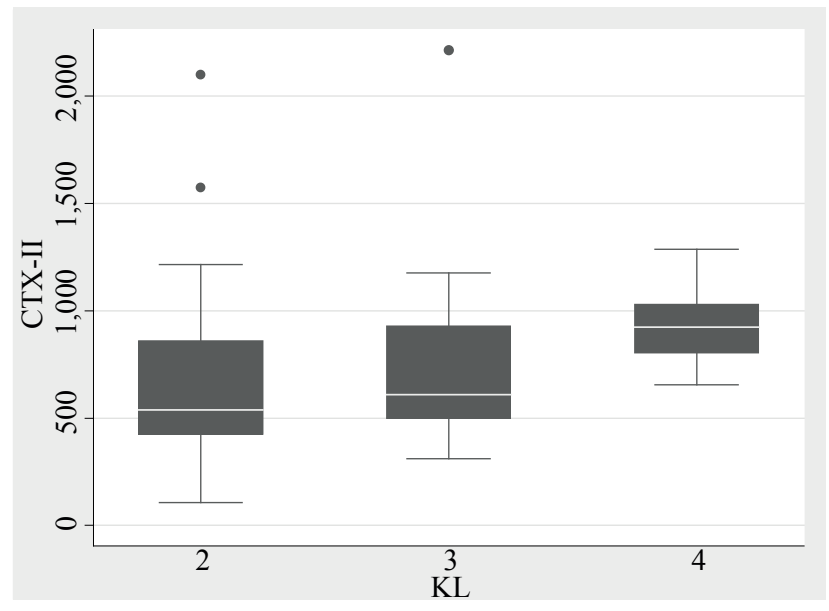

Figure 1. Box Plot of CTX-II among the KL Groups.

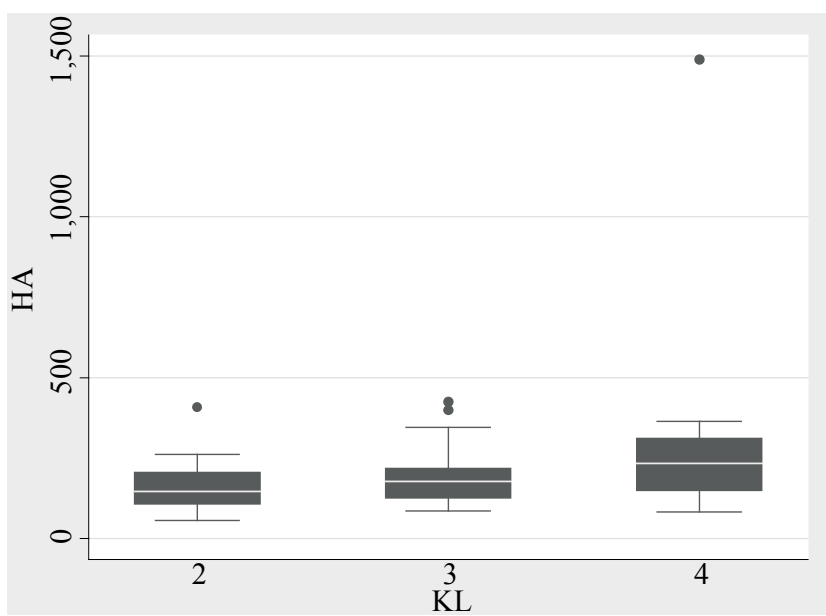

Figure 2. Box Plot of HA among the KL Group.
The mean differences of CTX-I among KL II, III, and IV were not significant, $p>0.05$ (Table 2). The mean of CTX-II in KL IV was 1.004, which was significantly higher (mean=1004.9) than that in KL III (mean=731.14, $p=0.021$ ). The result also showed the mean differences of HA levels in KL IV were higher (mean=209.85) than those in KL III (mean=209.85) $(p=0.151)$. No significant mean was found between CTX-I and OA severity. We found no correlation between inflammatory biomarkers (IL-1 $\beta$, hs-CRP) and OA severity.

The correlation of KL grade in Table 3 are shown significant with CTX-II $(p=0.001, \quad \mathrm{r}=0.412)$ and HA $(p=0.0411, \mathrm{r}=0.269)$. Table 3 shows that $\mathrm{KL}$ grade was not significantly associated with CTX-I ( $p=0.8364, \mathrm{r}=-0.0272)$; IL-1 $\beta(p=0.5773, r=0.0853)$ and hs-CRP $(p=0.2625$, $\mathrm{r}=0.1470)$.

Figure 1 and 2 show the mean difference of CTXII and HA among the KL grade II, grade III, and grade IV groups. The mean of CTX-II and HA are consistently increasing from KL grade II to grade III group, and from grade III group to grade IV group.

\section{Discussion}

According to OA Biomarkers Network recommendation on osteoarthritis, study on biomarkers should be differentiated on its role in burden of disease, investigation, prognosis, efficacy and, diagnosis of OA. $(20,21)$

Burden of disease markers assess the severity or extent of disease, typically at a single point of time, among individuals with OA. This can be thought of as severity within articular joint, and/or severity in terms of number of joints involved.(20) Several studies have shown that CTXII, HA, pyridinoline (PYD), cartilage oligomeric matrix protein (COMP), matrix metalloproteinase (MMP), tissue inhibitor of matrix metalloproteinase (TIMP), and YKL-D can be included in this category. $(20,21)$

This study showed that CTX-II was signficantly correlated with knee OA severity. This result is in accordance to results of most studies $(22,23,24,20,4)$. Conflicting results on CTX II was reported by Kalai who concluded that there was no significant correlation between CTX-II with a degree of joint gap narrowing.(16) Van Spil reported the lack of specificity of CTX-II as a possible cause, finding that changes in CTX-II were not pararel with other cartilage specific biomarkers changes.(25) This could also be due to differences in subgroup populations between studies.

The correlation of KL grade was significant with CTXII and HA. KL grades were not significantly associated with 


\section{CTX-I, IL- $1 \beta$ and hs-CRP.}

In Mann-Whitney U test, no significant mean difference was found statistically between HA concentration and KL grade. These results are different compared to other studies. (7-11,14) We exclude the possibility of HA fluctuation due to inflammatory condition because no significant difference of IL-1 $\beta$ and hs-CRP between groups was found in this study. In our opinion, this conflicting result might be due to small sample size because the trend showed higher HA in KL 3 and KL 4.

The weakness of this study was that biomarkers fluctuation related to joint degradation process could not be adequately assessed by cross sectional method and small sample size might also affect result of the statistical analysis.

Serum levels of CTX-I, CTX-II urine and serum HA might not represent the actual level inside the affected joint, since most of the patients had bilateral knees involvement. To minimize the bias, in this study we excluded subjects with multiple joints involvement and only included those with higher KL score in patients with bilateral knee OA. Thus with those study limitations, results of this study may not represent the general population, in particular due to the small sample size.

\section{Conclusion}

CTX-II and HA were associated with the severity of knee OA, suggesting that CTX-II can be used as a marker for knee OA severity.

\section{References}

1. Abramson SB, Attur M. Developments in the scientific understanding of osteoarthritis. Arthritis Res Ther. 2009; 11: 227.

2. Meulenbelt I, Kloppenburg M, Kroon HM, Houwing-Duistermaat JJ, Garnero P, Hellio Le Graverand MP, et al. Urinary CTX-II levels are associated with radiographic subtypes of osteoarthritis in hip, knee, hand, and facet joints in subject with familial osteoarthritis at multiple sites: the GARP study. Ann Rheum Dis. 2006; 65: 360-5.

3. Patra D, Sandell LJ. Recent advances in biomarkers in osteoarthritis. Curr Opin Rheumatol. 2011; 23: 465-70.

4. Cibere J, Zhang H, Garnero P, Poole AR, Lobanok T, Saxne T, et al. Association of biomarkers with pre-radiographically defined and radiographically defined knee osteoarthritis in a population based study. Arthritis Rheum. 2009; 60: 1372-80.

5. Solignac M. Biological markers for osteoarthritis: data from the ECHODIAH cohort. Presse Med. 2004; 33(9 Pt 2): 13-5.

6. Jordan KM, Syddall HE, Garnero P, Gineyts E, Dennison EM, Sayer AA, et al. Urinary CTX-II and glucosyl-galactosyl-pyridinoline are associated with the presence and severity of radiographic knee osteoarthritis in men. Ann Rheum Dis. 2006; 65:871-7.

7. Goldberg RL, Huff JP, Lenz ME, Glickman P, Katz R, Thonar EJ.
Elevated plasma levels of hyaluronate in patients with osteoarthritis and rheumatoid arthritis. Arthritis Rheum. 1991; 34: 799-807.

8. Hedin PJ, Weitoft T, Hedin H, Engström-Laurent A, Saxne T. Serum concentrations of hyaluronan and proteoglycan in joint disease. $\mathrm{J}$ Rheumatol. 1991; 18: 1601-5.

9. Sharif M, George E, Shepstone L, Knudson W, Thonar EJ, Cushnaghan $\mathrm{J}$, et al. Serum hyaluronic acid level as a predictor of disease progression in osteoarthritis of the knee. Arthritis Rheum. 1995; 38(6): 760-7.

10. Nagaya H, Ymagata T, Ymagata S, Iyoda K, Ito H, Hasegawa Y, et al. Examination of synovial fluid and serum hyaluronidase activity as a joint marker in rheumatoid arthritis and osteoarthritis patients (by zymography). Ann Rheum Dis. 1999; 58: 186-8.

11. Pavelka K1, Forejtová S, Olejárová M, Gatterová J, Senolt L, Spacek $\mathrm{P}$, et al. Hyaluronic acid levels may have predictive value for the progression of knee osteoarthritis. Osteoarthritis Cartilage. 2004; 12: $277-83$.

12. Jung YO, Do JH, Kang HJ, Yoo SA, Yoon CH, Kim HA, et al. Correlation of sonographic severity with biochemical markers of synovium and cartilage in knee osteoarthritis patients. Clin Exp Rheumatol. 2006; 24: 253-9.

13. Anitua E, Sanchez M, de la Fuente M, Azofra J, Zalduendo M, Aquirre $\mathrm{JJ}$, et al. Relationship Between Investigative Biomarkers and Radiographic Grading in Patients with Knee Osteoarthritis. Int J Rheumatol. 2009; 2009: 747432

14. Inoue R, Ishibashi Y, Tsuda E, Yamamoto Y, Matsuzaka M, Takahashi I, et al. Knee osteoarthritis, knee joint pain and aging in relation to increasing serum hyaluronan level in the Japanese population. Osteoarthritis Cartilage. 2011; 19: 51-7.

15. Golightly YM, Marshall SW, Kraus VB, Renner JB, Villaveces $\mathrm{A}$, Casteel $\mathrm{C}$, et al. Biomarkers of incident radiographic knee osteoarthritis: do they vary by chronic knee symptoms?. Arthritis Rheum. 2011; 63: 2276-83.

16. Kalai E, Bahlous A, Charni N, Bouzid K, Sahli H, Chelly N, et al. Increased urinary type II collagen C-telopeptide levels in Tunisian patients with knee osteoarthritis. Clin Lab. 2012; 58:209-15.

17. Criscione LG, Elliot AL, Stabler T, Jordan JM, Pieper CF, Kraus VB. Variation of serum hyaluronan with activity in individuals with knee osteoarthritis. Osteoarthritis Cartilage. 2005; 13: 837-40.

18. Kong SY, Stabler TV, Criscione LG, Elliott AL, Jordan JM, Kraus VB Diurnal variation of serum and urine biomarkers in patients with radiographic knee osteoarthritis. Arthritis Rheum. 2006; 54: 2496504.

19. Madan-Sharma R, Kloppenburg M, Kornaat PR, Botha-Scheepers SA, Le Graverand MP, Bloem JL, et al. Do MRI features at baseline predict radiographic joint space narrowing in the medial compartment of the osteoarthritic knee 2 years later?. Skeletal Radiol. 2008; 37: 805-11.

20. Bauer DC, Haunter DJ, Abramson SB, Attur M, Corr M, Felson D, et al. Classification of osteoarthritis biomarkers: a proposed approach. Osteoarthritis and Cartilage. 2006; 14: 723-7.

21. Rousseau JCh, Garnero P. Biological markers in osteoarthritis. Bone. 2012; 51: 265-77.

22. Christgau S, Garnero P, Fledelius C, Moniz C, Ensig M, Gineyts E, et al. Collagen type II C-telopeptide fragments as an index of cartilage degradation. Bone. 2001; 29: 209-15.

23. Reijman M, Hazes JM, Bierma-Zeinstra SM, Koes BW, Christgau $\mathrm{S}$, Christiansen C, et al. A new marker for osteoarthritis: crosssectional and longitudinal approach. Arthritis Rheum. 2004; 50: 2471-8.

24. Kong SY, Stabler TV, Criscione LG, Elliott AL, Jordan JM, Kraus VB. Diurnal variation of serum and urine biomarkers in patients with radiographic knee osteoarthritis. Arthritis Rheum. 2006; 54: 2496504. 
25. van Spil WE, Jansen NW, Bijlsma JW, Reijman M, DeGroof J, Welsing PM, et al. Clusters within a wide spectrum of biochemical markers for osteoarthritis: data from CHECK, a large cohort of individuals with very early symptomatic osteoarthritis. Osteoarthritis Cartilage. 2012; 20: 745-54. 